\title{
Lost Mars mission thrusts Russian space science further into crisis
}

\begin{abstract}
Washington, Moscow \& London. Despite predictions of an imminent collapse, most observers agree that Russia's space science establishment is likely to survive last week's loss of the Mars 96 spacecraft. But survival will probably be at a reduced level. And Russian space scientists will almost certainly never regain the leading role they once played in planetary exploration.

In fact, the loss of the spacecraft, when combined with the apparent failure of the Proton launch system and worsening problems with Russian participation in the international space station, appears to have brought the nation's space programme to a point of crisis.
\end{abstract}

Mars 96 cost Russia $\$ 122$ million and collaborators from 20 countries another $\$ 180$ million, according to figures released in Moscow on Monday. The spacecraft re-entered the atmosphere after an upper stage boosted by a Proton rocket failed to work properly. Russian space scientists and engineers had been working on the project for nearly a decade, and its launch had been postponed for two years from the originally planned date.

While a hastily formed committee began investigating the technical causes of the failure, dejected scientists at the Russian space research institute (IKI), which sponsored the mission, began studying options for reviving the mission. One idea, according to Thomas Duxbury of the US Jet Propulsion Laboratory, a participating scientist in Mars 96 who attended the launch, would be to re-fly many of the same instruments on a smaller spacecraft, since most have spares already built. The United States launched a similar mission this month, called the Mars Global Surveyor, to recover most of the data from the lost Mars Observer spacecraft.

Planetary scientists were encouraged by comments from officials of the Russian Academy of Sciences, who said this week that they would continue to support Russia's planetary exploration programme, even if it meant shifting resources from planned astrophysics missions to pay for it. But a recovery flight - if it materializes - will not happen quickly. Yuri Koptev, director general of the Russian space agency, says there will be no attempt to reach Mars again for at least five years.

A recovery flight also would have competition. Both Russia and the US National Aeronautics and Space Administration (NASA) have already made preliminary plans for a joint mission in 2001, with Russia providing a surface rover to complement an

American orbiter. Some of the Mars 96 lander instruments could possibly be shifted to the rover, said Duxbury.

A Russian instrument is also scheduled to fly on a US Mars lander due for launch in 1998. An international Mars exploration working group will meet in Florida next month, following the launch of NASA's Mars Pathfinder spacecraft, to consider these and other plans for future Mars missions.

Initial reactions from European and American scientists suggest that Russia will remain a welcome partner in such projects. Western scientists admit to being upset at the lack of rigorous hardware testing that preceded the Russian launch. According to Duxbury, however, the level of pre-launch testing for Mars 96 was much higher than for the last Russian attempt at Mars in the 1980s.

Despite the Mars 96 loss - and the fact that all but one Russian Mars mis- Up in smoke: After a perfect lift-off, failure of sion since the 1960s the launcher's upper stage led to disaster.

has failed - many international investigators say they would still continue to work with IKI in the future, and expect the Russian space science programme to survive. "Space science is too big an industry in Russia to be affected in any major way," says Jean André Sauvaud, a Mars 96 researcher with the French Centre National de la Recherche Scientifique (CNRS).

But money remains a worsening problem. The contractors who built different parts of the Mars 96 spacecraft reported after last weekend's launch failure that they had not been paid in months. "At least one reason for this greatest misfortune in our Martian programme is evident," says Alexander Alferov, scientific secretary of the Russian Academy of Sciences Council for the Cosmos. "Talented people are leaving space research teams because of poor financing."

Another negative result of the Mars 96 failure may be a loss of revenue from the country's commercial Proton sales. The rocket, which is normally highly reliable, has now suffered two recent upper-stage failures, and this may well drive away some potential customers.

The country's manned spaceflight programme, which represents by far the larger share of space funding, is already on the verge of financial disaster. NASA officials

flew to Moscow this week for a series of urgent meetings with their Russian counterparts aimed at resolving schedule and funding problems that are related to the international space station.

Most observers now expect the schedule for Russian delivery of station components to slip, and NASA is likely to face renewed criticism in the US Congress for its reliance on Russian hardware. Furthermore, Congress is keen to see hard currency flowing.

Marcia Smith, a Russian space programme expert with the US Congressional Research Service, warns that all these problems should not necessarily be lumped together. The Mars 96 failure, if it turns out to be due to the rocket upper stage, should be combined with other recent international launch failures like the European Ariane and the US Pegasus. It may not be proof, says Smith, that financial problems have eroded the quality of Russian science missions, as the spacecraft had no chance to prove itself.

At the same time, even with a commitment from the Academy of Sciences, Russia's space scientists, left with no mission to work on until 2001, will be struggling to stay afloat. The IKI itself may survive, but it may lose staff. Even if the rocket, and not the spacecraft, is to blame for the Mars 96 disaster, says Smith, "it just so happens it was carrying the one spacecraft on which the whole of the Russian space science community was riding".

Tony Reichhardt,

Carl Levitin \& Ehsan Masood 